\title{
Evaluating the Instructional Materials for Peer Assisted Learning Program (PALP)
}

\author{
Arilia Triyoga ${ }^{1}$ \\ ${ }^{1}$ Universitas Ahmad Dahlan, Yogyakarta, Indonesia \\ Correspondence: Arilia Triyoga, Universitas Ahmad Dahlan, Yogyakarta, Indonesia. E-mail: arilia@pbi.uad.ac.id
}

Received: November 6, 2018

Accepted: December 1, 2018

Online Published: December 28, 2018

doi:10.5539/ass.v15n1p37

URL: https://doi.org/10.5539/ass.v15n1p37

\begin{abstract}
ESL classroom implements the use of instructional materials to support instruction in classroom. Instructional material is defined as anything which is deliberately used to increase the learners' knowledge and/or experience of the language (Tomlinson, 2011). Textbook, video, newspaper can be used as materials in the English instruction. This research aims to evaluate the instructional material for Peer Assisted Learning Program (PALP) based on Mukundan's categorization in the form of English Language Teaching Textbook Evaluation Checklist (ELT-TEC) (2013) and to find whether the material is useful or not the material for PALP. Peer Assisted Learning Program (PALP) is a peer tutoring program initiated by the English Education Department to encourage the students to speak English fluently and to perform better. The data of this descriptive quantitative research are taken from the instructional material for PALP and these are classified based on the categorization checklist of Mukundan's English Language Teaching Textbook Evaluation Checklist (ELT-TEC). The total score will be the consideration of the materials' usefulness. Based on the analysis, it is found that the instructional material for PALP is on the moderate usefulness. This finding can give a significant contribution the PALP itself.
\end{abstract}

Keywords: PALP, instructional material, evaluation

\section{Introduction}

Peer Assisted Learning Program (PALP) is a cross level peer tutoring in one institution initiated by the English Education Study Program of Ahmad Dahlan University Yogyakarta in 2015. This is a compulsory program for the first, second and the third semester students. Similar as other formal instructional processes, PALP is completed with syllabus and instructional materials. The materials for PALP help the tutors to teach the tutees effectively. Since language teaching is a dynamic process, the material and aids which are used by teacher to make his teaching very effective is called teaching aids and instructional material (Patel \& Jain, 2008).

The instructional materials of PALP are in the form of textbooks and these are provided in three series; General English for semester one, Speaking for semester two and Integrated English for semester three students. Tutors use the textbook in their instructional process. Along with the use of the textbooks, some problems appear. The problems commonly found by the tutors in using the books are the instruction on the book are sometimes unclear, some topics in the discussions are not up-to-date and these are not interesting for the tutees and the materials in some parts of the books do not represent the objective in the syllabus.

Considering the problems mentioned above, evaluating instructional materials for PALP is needed to ensure whether the books can facilitate the learning objective in PALP or not. For that, this research aims to evaluate the instructional material for Peer Assisted Learning Program (PALP). The rubric used to evaluate the instructional materials is English Language Teaching Textbook Evaluation Checklist (ELT-TEC) proposed by Mukundan (2013). ELT-TEC will show whether the material is useful or not for PALP.

\subsection{Literature Review}

Besides the teacher, students and teaching methods, the instructional process means nothing without instructional materials and evaluation (Cakir, 2015). Textbook is the instructional materials commonly used in the instructional process. Make in use textbook in classroom support peer tutoring. It also contributes to the development of students' academic performance. If the textbooks meets "usefulness" categorization in ELT-TEC proposed by Mukundan, it means that the textbook gives positive contribution for the instruction. 


\subsection{Peer Assisted Learning Program (PALP)}

Peer tutoring is broadly used to support the students' performance academically. Peer Assisted Learning Program (PALP) is a peer tutoring program initiated in 2015 by the English Education Department Ahmad Dahlan University Yogyakarta Indonesia. Peer tutoring is defined as the instructional involving older, more skilled or experienced individuals tutoring younger or less experienced tutees (Falchikov, 2002). In addition, O'Shea, L. J. and O'Shea, D. J. (2010) stated that peer tutoring is recognized as an effective method of instruction to help students increase their academic performance.

As another instructional process, PALP also needs instructional materials to make the instructional process run efficiently. Since this program is compulsory for the first, second and the third semester students, the instructional material represents the students' or the tutees' needs and level. The tutees use textbook as the source of their materials. The textbooks for PALP are General English for first semester students, Speaking for second semester students and Integrated English for third semester students.

\subsection{Instructional Materials}

The students or the learner can be easier to learn English in the classroom through the help of the instructional materials. Peter and Jain (2008) stated that the material and aids which are used by teacher to make his teaching very effective is called teaching aids and instructional material. The instructional materials can be found in various form to help the instruction run effectively and intensively. Moreover, Richard and Rodgers in Nunan (1991) suggest that instructional materials provide detailed specifications of contents, even in the absence of syllabus. The instructional materials give guidance to the teacher on both the intensity of coverage and the amount of attention demanded by particular content or pedagogical tasks.

The suitable and good instructional materials should meet several criteria. The instructional materials should become the supplement of oral teaching, motivate the students, prevent indiscipline and monotony, make learning permanent, save time and energy and it should provide direct experience (Patel \& Jain, 2008). When it meet the "usefulness" criteria, the instructional material can be made in use in the classroom. The teacher can use the instructional materials in the classroom through several various kinds of instructional materials. Those materials are commonly presented in textbook or course book.

\subsection{Textbooks}

In the English language classroom, textbook is considered as valuable thing. Khodabakhshi (2014) considered textbook as the visible heart of any ELT program which offers considerable advantages for both the student and the teacher. In addition, Khodabakhshi (2014) stated that textbooks play crucial role in the most EFL/ESL classroom, and it means textbooks are the second most important factor after the teacher in the language education. In the other words, textbooks give positive contribution in the classroom; providing guidance and structure, and saving busy teachers a great deal of time that would be otherwise spent preparing materials from scratch (Freebairn \& Torres, 1994). Furthermore textbooks provide structure and syllabus for a program, help standardize instruction, maintain quality, provide a variety of learning resources, efficient, can provide effective language models and input, can train teacher and they are visually appealing (Richard, 2001). Textbooks also need to meet good criteria to be used in the classroom. Patel and Jain (2008) proposed that a good textbook should be according the individual difference of students, should be according the objectives of teaching English, the subject matter should be well graded, exercise work and practical work should be given at the end of the chapter, must develop moral qualities in the students, should be no printing mistake, must not he very costly, the paper should be qualitative, the cover should be attractive and qualitative.

\subsection{Textbooks Evaluation}

The objective of the instruction become one of several considerations in choosing the appropriate textbooks. Textbooks evaluation is needed to know whether a certain book is appropriate or not in the instructional process. Tomlinson in Khodabakhshi (2014) defined materials evaluation as a procedure that involves the value's measurement (or potential value) of a set of learning materials. Cunningsworth (1995) suggests that we should ensure that careful selection is made, and that the materials selected closely reflect (the needs of the learners and) the aims, the methods and the values of the teaching program.

Furthermore, Tomlinson (2008) mentions two causes for learning failure. The first cause of failure is possibly motivated by the need of commercial success, which is, publishers would have to produce books based on the public demand. The second cause of failure is that instead of focusing on how learners could actually take benefit from using the textbook, textbook writers rely on their intuition and produce materials that they think would work best for their intended users (Tomlinson, 2008). Based on the reasons stated above, textbook 
evaluation becomes very important as part of the instruction. This paper will describe the evaluation of textbooks used in PALP.

\subsection{Review on the Relevant Studies}

Mukundan and Kalajahi (2013) evaluated Malaysian English language teaching textbooks. The used English Language Teaching Textbook Evaluation Checklist (ELT-TEC) in the terms of the general attributes and the learning-teaching contents of the Malaysian textbooks. It involved 944 male and female English teachers (Year 1 to Year 6 \& Form 1 to Form 5) evaluating the Malaysian English books. The result showed that the textbooks were 'highly useful' to the students while the school books were only 'moderately useful'.

Nazeer, Shah and Sarwat (2015) evaluated textbooks of secondary level, class 6th and 7th used in Pakistan. This research used adapted Mukundan's evaluation checklist. The results revealed that these textbooks lack in various vital features even in basic skills. The obtained results showed that these books need to be revised.

\subsection{Objective}

This research aims to evaluate the instructional materials for Peer Assisted Learning Program (PALP) and to find out the usefulness of the instructional materials for PALP.

\section{Method}

This research used descriptive quantitative research model. The data were gathered through the English Language Teaching Textbook Evaluation Checklist (ELT-TEC) proposed by Mukundan (Mukundan \& Kalajahi, 2013). There were eleven tutors of PALP as the evaluators because the mentors are the users of the textbooks used in PALP. The mentors are asked to give check mark the checklist forms based on their experience in using the textbooks for PALP. The evaluation checklist contains two main categories; i) The textbook general attributes ii) Textbook learning Content. There are five major components under general attributes which are (a) Syllabus and curriculum, (b) Methodology, (c) Suitability to learners, (d) Physical and Utilitarian Attributes, (e) Efficient outlay of supplementary materials. There are major components under learning-teaching contents which are (a) General content, (b) Listening, (c) Speaking, (d) Reading, (e) Writing, (f) Vocabulary, (g) Grammar, (h) Pronunciation, and (i) Exercise. The rating system is based on a 5-point scale; $0=$ NEVER TRUE; $1=$ RARELY TRUE; 2 = SOMETIMES TRUE; 3 =OFTEN TRUE; 4 = ALWAYS TRUE. In order to help the interpretation of the date easily, there is a table that provides information and guide to interpret the findings (Mukundan \& Kalajahi, 2013).

Table 1. Table Scores Interpretation Guide

\begin{tabular}{ccc}
\hline Level & Range & Interpretation \\
\hline 0 & $0.00-0.80$ & Negligible usefulness \\
1 & $0.81-1.60$ & Low usefulness \\
2 & $1.61-2.80$ & Moderate usefulness \\
3 & $2.81-3.60$ & High usefulness \\
4 & $3.61-4.00$ & Very high usefulness \\
\hline
\end{tabular}

\section{Results}

Table 2. General attributes of textbooks for PALP

\begin{tabular}{cc}
\hline Criteria & Mean \\
\hline The book in relation to syllabus and Curriculum & 2.58 \\
Methodology & 2.25 \\
Suitability to learner & 2.38 \\
Physical and utilitarian attributes & 2.24 \\
Efficient layout of supplementary materials & 2.20 \\
\hline
\end{tabular}

Table 3. Learning-teaching content of textbooks for PALP

\begin{tabular}{cc}
\hline Criteria & Mean \\
\hline General content & 2.56 \\
Listening & 2.23 \\
Speaking & 3.05 \\
\hline
\end{tabular}




$\begin{array}{cc}\text { Reading } & 2.45 \\ \text { Writing } & 2.67 \\ \text { Vocabulary } & 2.56 \\ \text { Grammar } & 2.49 \\ \text { Pronunciation } & 3,05 \\ \text { Exercises } & 2,64\end{array}$

Table 4. The evaluation of textbooks for PALP

\begin{tabular}{cc}
\hline Categories & Mean \\
\hline General attributes & 2.33 \\
Learning-teaching content & 2.63 \\
\hline
\end{tabular}

Table 5. The usefulness of textbooks for PALP

\begin{tabular}{ccc}
\hline Level & Range & Interpretation \\
\hline 2 & 2.48 & Moderate Usefulness \\
\hline
\end{tabular}

\section{Discussion}

\subsection{General Attributes of Textbooks for PALP}

The general attributes of textbooks for PALP were evaluated through ELT-TEC where the mentors gave check mark on the point scale. Richard (2001) stated that textbooks provide structure and syllabus for a program. This is proven on the Table 2. The mean of the book to syllabus and curriculum is quite high, 2.58 . The suitability of the books is shown with the mean 2.38. The method is presented in 2.25 while the utilitarian attributes is on 2.24. On the other hand, it seems that the books do not present efficient layout of supplementary materials, because the mean of this criterion is the lowest (2.20).

\subsection{Learning-teaching Content of Textbooks for PALP}

The learning-teaching content of textbooks for PALP was also evaluated. The content evaluated were the context in general, the skills (listening, speaking, reading and writing), the micro skills (vocabulary, grammar and pronunciation) and also their exercises. The highest mean in the Table 3 is for speaking and pronunciation (3.05) where the lowest mean is shown in the listening (2.23). The mean for the general content of the book and also the vocabulary is quite high (2.56). In the table 3 , it also can be seen that the mean for writing skill is 2.67 and the mean for exercises is 2.64 . Reading and grammar get the almost similar mean, they are 2.45 for reading and 2.49 for grammar.

\subsection{The Evaluation of Textbooks for PALP}

Table 4 refers to the sum up of the textbooks' evaluation based on its general attributes and its learning-teaching content. The mean for the evaluation of the textbooks for PALP for their general attributes is 2.33. Based on the score interpretation guide proposed by Mukundan (2013) this mean is on level 2. It can be interpreted that the usefulness of the textbooks for PALP is in the moderate usefulness categorization. In addition, considering the mean of the textbooks for PALP based on its learning-teaching content, the usefulness of the textbooks for PALP is also in moderate usefulness. It is based on the mean of learning-teaching content (2.63) where this mean is categorized in the level 2.

\subsection{The Usefulness of Textbooks for PALP}

Based on the evaluation of the tutors of PALP, the usefulness of the textbooks for PALP can be seen in the table 5. The mean of the evaluation of the textbooks for PALP is 2.48. This evaluation consists evaluation on the textbooks' general attributes and their learning-teaching contents The mean is on the level 2 and it can be interpreted that the textbooks for PALP is moderately useful. This result is in congruence with Mukundan and Kalajahi (2013) that used the same checklist but it evaluates different textbooks. In conclusion, the textbooks for PALP is moderate to be used and it still needs some betterments and revisions in some aspects.

\subsection{Conclusion}

Considering that the textbooks give very important contribution, the textbooks evaluation is very crucial. Textbook evaluation is considered as a very substantial thing because the information collected can be used in 
making decisions about the future of the textbooks (Mukundan, 2013). The tutors of PALP evaluated the textbooks for PALP using English Language Teaching Textbook Evaluation Checklist (ELT-TEC) by Mukundan. The evaluation covered the textbooks' general attributes and also their learning-teaching content. The result is shown that the mean for the textbooks' general attribute is in 2.33 and their learning-teaching contents is in 2.63. Based on the mean of the textbooks general attributes and their learning-teaching contents, it can be sum up that the evaluation of the textbooks for PALP is in level 2 with the mean range in 2.48. This means that the textbooks for PALP is moderate to be used in the instruction or in the program.

\section{References}

Çakir, İ. (2015). Instructional Materials Commonly Employed by Foreign Language Teachers at Elementary Schools. International Electronic Journal of Elementary Education, 8(1), 69-82.

Cunningsworth, A. (1995). Choosing Your Coursebook. Oxford: Heinemann Publishers Ltd.

Falchikov, N. (2002). Learning Together-Peer Turtoring in Higher Education. New York: Routledge Falmer.

Hutchinson, T., \& Torres, E. (1994). The textbook as agent of change. ELT Journal, 48(4), $315-328$. https://doi.org/10.1093/elt/48.4.315

Khodabakhshi, M. (2014). Choose a Proper EFL Textbook: Evaluation of "Skyline" Series. Proceedings of International Conference on Current Trends in ELT, Iran, 98, 959-967. https://doi.org/10.1016/j.sbspro.2014.03.505

Mukundan, J., \& Kalajahi, S. A. R. (2013). Evaluation of Malaysian English Language Teaching Textbooks. International Journal of Education \& $\quad$ Literacy $\quad$ Studies, $\quad 1(1), \quad 38-46$. https://doi.org/10.7575/aiac.ijels.v.1n.1p.38

Nazeer, M., Shah, S. K., \& Sarwat, Z. (2015). Evaluation of Oxon English Textbook Used in Pakistan Public Schools for 6th \& 7th Grade. Journal for the Study of English Linguistics, 3(1), 51-79. https://doi.org/10.5296/jsel.v3i1.7778

Nunan, D. (1991). Language Teaching Methodology. Prentice Hall International English Language Teaching.

O'Shea, L. J., \& O'Shea, D. J. (2010). Peer Tutoring. International Encyclopedia of Education (3rd ed., pp. 802-807). https://doi.org/10.1016/B978-0-08-044894-7.01139-8

Patel, M. F., \& Jain, P. M. (2008). English Language Teaching (Methods, Tools and Techniques). Jaipur: Sunrise Publishers \& Distributors.

Richard, J. C. (2001). Curriculum Development in Language Teaching. UK: Cambridge University Press. https://doi.org/10.1017/CBO9780511667220

Tomlinson, B. (2011). Materials Development in Language Teaching. Cambridge: Cambridge University Press.

Tomlinson, B. (Ed.) (2008). English Language Learning Materials: A Critical Review. London: Continuum.

\section{Copyrights}

Copyright for this article is retained by the author(s), with first publication rights granted to the journal.

This is an open-access article distributed under the terms and conditions of the Creative Commons Attribution license (http://creativecommons.org/licenses/by/4.0/). 